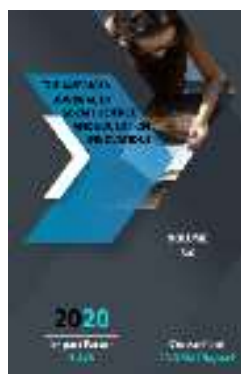

\title{
The Role Of Spiritual And Moral Education In Personal Development
}

\section{S.M.Yuldasheva}

Associate Professor Of The Department Of Pedagogy And Psychology, Uzbek State World Languages University, Tashkent, Uzbekistan

Journal Website:

http://usajournalshub.c om/index,php/tajssei

\section{Copyright: Original} content from this work may be used under the terms of the creative commons attributes 4.0 licence.

\section{ABSTRACT}

The issues of spiritual and moral education, healthy lifestyle and the formation of spiritual and moral immunity and prevention of threats to them are becoming increasingly important in the development of the individual. This article identifies the content of harmful habits, vices, shortcomings in the upbringing of the individual, analyzes the factors that influence their pedagogical influence in the family and the formation of the spiritual worldview.

\section{KEYWORDS}

Education, spirituality, spiritual threat, family, selfishness, child's personality.

\section{INTRODUCTION}

One of the global problems of the XXI century is the issues of personal development including spiritual and moral education in personal development, the formation of a healthy lifestyle and spiritual and moral immunity in families and their protection from spiritual threats. Indeed, on this issue, President Sh.M.Mirziyov said, "Bringing up our children as independent-minded, truly patriotic people will never lose its relevance for us."
The first President of Uzbekistan I.A.Karimov also drew public attention to this problem in many of his works, especially "Uzbekistan on the threshold of the XXI century: a threat to security, conditions of stability and guarantees of development" and "High spirituality is an invincible force."

Spiritual and moral upbringing of the individual, upbringing the youth in a healthy 
and harmonious way, strengthening the family that ensures the continuity of generations, increasing its prestige, inculcating in the minds of young people the responsibility to improve a high-spirited, healthy generation is becoming an urgent task for today. Indeed, as mentioned above, the issue of child upbringing, a healthy generation is the main force that determines the future not only of the family, but also of the state, society. A person with high spirituality, on the other hand, has the characteristics of a family man, a patriot and a mature specialist.

So let's analyze what is reflected in the content of harmful habits, vices, inaccuracies in the upbringing of children in the family. First of all, it appears in the cases of deviation of his behavior from moral criteria. That is, disrespect, rudeness, laziness appear mental disorders including inhumanity, flipancy, irritability, reluctance and addiction to harmful habits, and these conditions lead to the formation of spiritual and moral depravity in children. This, in turn, creates a process of erosion, cracking in the development of the individual, there is a deviation from the spiritual-moral criteria, and in the young organism it leads to the collapse of immunity to the fight against any content, including spiritual threats.

Spiritual threats are the most dangerous attacks on the moral consciousness of the individual and society. Spiritual threats, in addition to affecting a person's free life and spiritual world, are considered dangerous by causing negative situations in his family, disrupting a healthy lifestyle. This is a serious pedagogical problem. Undoubtedly, the role and influence of the family in raising the unique spirituality of any nation is incomparable. Because the purest and clearest feelings of a person are formed first of all in the heart of the family. Also, the spiritual criteria and views that determine a person's character, nature and worldview, the first ideas about these relationships are formed in the family environment, from the example of the parents.
From this point of view, family upbringing is the main tool in the formation of a person's spirituality, and we can not deny that the issue of a healthy generation also plays an important role in the upbringing of children. In this sense, one of the main tasks of reforms in this area is to bring up young people in a healthy and harmonious way, to form in their minds the idea that "a healthy lifestyle is a healthy family, a healthy family is a healthy child, a happy future."

\section{MATERIALS AND METHODS}

At this point, first of all, there is a need to determine the factors that lead to or are the basis of an unhealthy lifestyle, the pedagogical content of the concept of spiritual threats. Spiritual threats are a set of vices that create negative perceptions, feelings, traits, and qualities in a person's moral consciousness, and are deliberate attacks aimed at destroying a person mentally and morally. From a pedagogical point of view, it is recognized that spiritual threats are a set of factors that negatively affect the social, moral and cultural formation of an individual. A socially, morally, and culturally incorrectly formed person is an unhealthy spouse, an ignorant person. Ignorant people, on the other hand, lead to an unhealthy environment in the family, to the formation of unhealthy families, to the disintegration of families, and thus to the destruction of the spiritual environment in society.

The philosopher Abu Nasr al-Farabi (873-950) analyzed the concept of virtue and ignorance and said, "Virtuous people with human qualities build a virtuous society, and conversely, ignorant people with ignorant vices live in an ignorant life."

In this sense, spiritual threats are the vices of spiritual and moral depravity that turn people into ignorant people and promote unhealthy lifestyles. Those who deviate from the rules and norms of society are called "difficult to bring up." Basically, children with difficult 
upbringing form a corrupt environment in unhealthy families. It is well known that " difficult to bring up" means resistance to pedagogical influence. It is studied through the phenomenon of deviation in science that upbringing is difficult, the accepted norms and rules are not followed by the pupil. Such deviant behavior is the result of society's or the family's disregard for the child's personality.

Thus, the content of spiritual threats has its own characteristics, and the prevention of threats is carried out by shaping the spiritual outlook of the individual in the family and increasing attention to the factors of a healthy lifestyle.

From the above we can draw the following conclusions:

First, the content of spiritual threats is a set of subjective factors that represent the vices of spiritual and moral inferiority in the family; Second, spiritual threats are manifested today, from a pedagogical point of view, in the form of malpractices that promote social, moral and cultural depravity and lead to unhealthy marriage; Third, moral threats are a risk that consists of a set of unhealthy ideas aimed at disrupting the moral consciousness of the individual through the promotion of an unhealthy lifestyle. Spiritual threats have a negative impact on an individual's morality as a defect of spiritual-moral inferiority. In this regard, the first President of Uzbekistan I.A. Karimov said: "If we do not fight against such dangers in a timely and resolute manner, it's not hard to imagine that various harmful currents will invade our country, attract our young people, and as a result, they will not be able to think about their duties and responsibilities to their parents, families and the country, become selfish people who live a one-day life. I would like this truth to be deeply understood by every person in our country, every parent, and most importantly, every boy and girl."
Observations show that spiritual threats today are manifested by the promotion of the following vices: selfishness, impurity, being slave to lust, indulgence, challlenging a lighthearted life, addiction, fanaticism, aggression, hunger for wealth, moral depravity, violence, accepting immorality as a culture, indifference, reluctance, negligence.

\section{RESULT AND DISCUSSION}

These vices of spiritual and moral depravity create an unhealthy environment in families, and they enter families "smoothly" through various news, movies, works of culture and art, music, articles and even food.

For example, "Selfishness" is a moral defect in which a person "puts his own interests first" in the family and society and strives to live only for himself. This vice, contrary to the social qualities, creates misconceptions and views in the moral consciousness of the individual and leads families to disintegration. That is why selfish people do not have a sense of duty and responsibility. Such people live only by thinking of the present, devoid of the qualities of thinking of tomorrow, fighting for goodness and truth. Lack of duty and responsibility in a person's morality is also a socio-moral defect, and this is one of the defects that lead to the breakdown of the family. The German philosopher Friedrich Gegel (1770-1831) divided the duties and responsibilities of man into four: for himself (to be knowledgeable, virtuous), for his family (providing for the family and raising their children to be educated and moral), for other people (to treat people fairly, ethically, to respect their rights) and for the country (to be in the civil service and to protect his motherland). In this case, a sense of duty and responsibility creates qualities of virtue, family, humanity, and community in the individual's morality as opposed to selfishness, and prevents spiritual threats. Based on the above evidence, we can conclude that the importance of spiritual and moral education in the development of the individual is great and it is important to pay close attention to the 
formation of the spiritual and moral immunity of the family in order to create a spiritual and moral environment in the family, to protect it from spiritual threats.

Given the importance of spiritual and moral education in the development of the individual, it is recommended to pay special attention to a number of factors in the formation of a person's spiritual and moral immunity:

- $\quad$ The first factor is the formation of a person's worldview, character and behavior on the basis of human criteria;

- $\quad$ The second factor is the observance of the criteria of politeness and chastity in the upbringing of the individual and the formation of the most important human qualities and attributes in the morality of the individual;

- The third factor is the development of opportunities to increase the effectiveness of spiritual and moral education of the individual;

- $\quad$ - The fourth factor is the formation of a healthy lifestyle in the family, society, educational institutions and out-ofschool educational institutions, orphanages;

- $\quad$ The fifth factor is to pay attention to the content of the qualities of humanism, patriotism, loyalty to national values in the preparation of young people for family life;

- The sixth factor is the implementation of ongoing propaganda work with the family, community, educational institutions, non-governmental nonprofit organizations, the media and health workers. formation of the most important human qualities and attributes in children and the composition of healthy lifestyles.

\section{REFERENCES}

1. Qaxxarova, M., \& Absattorov, B. M. (2020). EVOLUTION OF VIEWS ON ETHICS, ETHICAL CRITERIA AND ETHICAL STANDARDS. The Light of Islam, 2020(1), 110-115.

2. Qaxxarova, M., \& Raximshikova, M. (2020). MORAL CONTINUITY IS A SOCIALPHILOSOPHICAL, HISTORICAL PHENOMENON. The Light of Islam, 2020(3), 103-112.

3. Karabaevna, Z., Musurmanova, A., Xamroevich, R. (2019). IMPROVING THE COMPETENCE OF FUTURE VOCATIONAL EDUCATION TEACHERS BASED ON MODULAR-RATING EDUCATIOTN. International Journal of Engineering and Advanced Technology, 2019, 9(1), c. 69036906

\section{CONCLUSION}

In conclusion, strengthening the spiritual and moral education in the development of the individual can be achieved primarily by paying special attention to the educational process, increasing its national characteristics, the 